\title{
COMPARISON OF SOCIAL SKILLS BETWEEN INTACT PUPILS AND PUPILS WITH SPECIAL EDUCATIONAL NEEDS IN MAINSTREAM PRIMARY SCHOOLS
}

\author{
[KOMPARACIA SOCIALNYCH ZRUCNOSTI ZIAKOV \\ INTAKTNYCH A ZIAKOV SO SPECIALNYMI VYCHOVNO- \\ VZDELAVACIMI POTREBAMI V BEZNEJ ZAKLADNEJ SKOLE]
}

\author{
Eva Lorinczova - Robert Tomsik
}

\section{doi: 10.18355/PG.2017.6.1.2}

\begin{abstract}
When pupils with special educational needs are trying to build relationships with their classmates, they may encounter some difficulties. In this context, an important condition for the development of positive relationships and participation with peers is to possess relevant social skills. Hence, the present study concentrates on the social skills of intact pupils and pupils with special educational needs. The data were collected through modified Assessment scale (SSRS; Gresham, Elliott, 1990). The research sample consisted of 105 students in $9^{\text {th }}$ grade of Slovak mainstream primary schools. The results were analyzed on the basis of the following three variables: Cooperation, Assertiveness, and Empathy. The results proved that intact pupils reached higher average value of social skills than pupils with special educational needs and it can be concluded that students with special educational needs have greater problems with empathic behavior when interacting with their peers which can gradually lead to the feelings of loneliness or separation.
\end{abstract}

\section{Key words}

Inclusive education, social skills, pupils with special needs, cooperation, assertion, empathy.

\begin{abstract}
Anotácia
Žiaci so špeciálnymi výchovno-vzdelávacími potrebami môžu mat' v školskej triede t’ažkosti pri budovaní vzt'ahov so svojimi rovesníkmi. Dôležitou podmienkou pre rozvíjanie pozitívnych vzt'ahov, participácie s rovesníkmi je disponovat' relevantnými sociálnymi zručnost’ami. Táto štúdia opisuje sociálne zručnosti intaktných žiakov a žiakov so špeciálnymi výchovno-vzdelávacími potrebami. Prostredníctvom upravenej posudzovacej škály (SSRS; Gresham, Elliott, 1990) sa vykonával zber dát na vzorke 105 žiakov 9. tried bežných základných škôl. Analýza sa zakladala na troch premenných: Spolupráca, Asertivita, Empatia. Výsledky naznačujú, že priemerné hodnoty sociálnych zručností intaktných žiakov sú vy̌šie ako u žiakov so ŠVVP a možno konštatovat', že žiaci so ŠVVP majú väčší problém s empatickými prejavmi voči svojim rovesníkom, čo môže postupne viest' k pocitom osamelosti alebo odlúčenia.

Kl’účové slová

Inkluzívne vzdelávanie, sociálne zručnosti, žiak so ŠVVP, spolupráca, asertivita, empatia.
\end{abstract}




\section{Úvod}

Vo všeobecnosti žijeme v čase silného tlaku na l'udskú psychiku. Čas vel'kých nádejí, ale aj čas vel'kých sklamaní. Čas plný dynamiky, rýchlosti, čas útekov do prírody a samoty, útekov k sebe samému. Súčasnost' vyžaduje človeka, pre ktorého jedinou istotou bude to, že si bude verit', že bude vediet', chciet', milovat' a tvorit' (Zelina, 2011). V školskom prostredí by sme mali pre žiakov vytvárat' relatívne pokojné, nestresové prostredie, kde by sa cítili príjemne, viac sa sústredili na školskú prácu, lepšie využívali svoje kapacity a rozvíjali svoju samostatnost', tvorivost', nadanie, talent, akceptáciu druhých, komunikatívnost'. Takéto prostredie by bolo vhodné aj pre inkluzívnu školu, ktorá sa primárne nesústred’uje len na žiakov takých a onakých, ale na efektívne spolunažívanie všetkých členov skupiny. Predpokladom úspešnej sociálnej inklúzie v školskom prostredí je aj adaptácia, socializácia a komunikácia. Pokial' absentuje jedna z týchto paradigiem je možnost', že to bude mat' na žiaka so špecifickými potrebami dopad, hlavne na jeho psychiku. Preto príspevok orientujeme na čast' problematiky inkluzívneho vzdelávania, ktorej sa vo všeobecnosti venuje menšia pozornost'. Je to doména participácie, socializácie s dôrazom na sociálne zručnosti žiakov intaktných a žiakov so špeciálnymi výchovno-vzdelávacími potrebami (d’alej už len ŠVVP) v bežnej základnej škole. Konkrétne sa zameriavame na sociálne zručnosti, ktoré sú považované za prediktor kvalitných sociálnych vzt'ahov v školskom prostredí (Elliott, Demeray, Malecki, 2001). Explicitne sa venujeme empatii, kooperácii a asertivite, pretože nedostatok sociálneho kontaktu s kamarátmi, nízka miera ovládania svojich emócií a negatívne sebapoňatie môžu viest' k problémom, ktoré sa môžu prejavovat' neskôr agresívnym správaním (Bender, Wall, 1994, Cambra, Silvestre, 2003) alebo sa žiak môže dostat' na okraj skupiny.

\section{Sociálny aspekt inkluzívneho vzdelávania}

Vzdelávanie žiakov so ŠVVP $v$ inkluzívnych triedach je dôležitým cielom vzdelávacej politiky viacerých krajín ${ }^{2}$. Aj samotní rodičia vo väčšej miere začleňujú svoje deti do bežných škôl (Ferguson, 2008). Za najväčšie výhody nepomenovávajú len akademické výhody, ale aj pozitívne prínosy socializácie (Frederickson, Dunsmuir, Lang , Monsen, 2004). Tie sa spájajú s príležitost'ou diet'at'a rozvíjat' si pozitívne vzt'ahy so svojimi rovesníkmi a začleňovat' sa do spoločenského života (Scheepstra, Nakken, Pijl, 1999; Sloper, Tyler, 1992).

$\mathrm{Na}$ druhej strane, medzinárodné štúdie opakovane ukázali, že zaradenie žiakov so ŠVVP nevedú automaticky $\mathrm{k}$ nárastu priatel'stva medzi týmito žiakmi a ich rovesníkmi (Buysse, Davis Goldman, Skinner, 2002; Guralnick, Neville, Hammond, Connor, 2007; Lee, Yoo, Bak, 2003). Takéto sociálne vylúčenie môže viest' neskôr k úplnej izolácií v spoločenskom živote. Nedostatok sociálneho kontaktu s kamarátmi, nízka miera ovládania sociálnych zručností a negatívne sebapoňatie vedú k problémom, ktoré sa môžu prejavovat' spomínaným agresívnym správaním (Bender, Wall, 1994; Cambra, Silvestre, 2003).

Vyčlenenie sociálneho aspektu inklúzie uvádzajú Koster, Nakken, Pijl, Van Houten (2009), ktorí rozlíšili a popísali sociálnu dimenziu inklúzie do troch zastrešujúcich konceptov - sociálna participácia, interakcia a sociálna inklúzia. S participáciou všetkých členov skupiny spájame sociálne zručnosti, ktoré vo všeobecnosti predstavujú schopnost' interakcie s ostatnými, či už prostredníctvom verbálnej alebo neverbálnej komunikácie. V školskom prostredí potom medzi intaktnými žiakmi a žiakmi so ŠVVP prebieha proces sociálneho učenia, kde majú možnost' rozvíjat'

\footnotetext{
${ }^{2}$ V SR podporujú akceptáciu inklúzie: Ústava SR č. 460/1992 (II. hlava, čl. 42); Zákon č. 365/2004 Z.z. (§32a, §32b, §32c); Zákon č. 245/2008 o výchove a vzdelávaní (§3, pís. c, d, e), následne aj d’alšie oficiálne dokumenty: Dohovor o právach ludú s postihnutím; Európska agentúra pre rozvoj špeciálneho a inkluzívneho vzdelávania.
}

Slavonic Pedagogical Studies Journal, ISSN 1339-8660, Volume 6 Issue 1, February 2017 
svoje sociálne zručnosti (Sollarova, 2008). Zahraničné výskumy upriamujú tiež pozornost' na sociálne učenie $\mathrm{s}$ dôrazom aj na prvky emocionálneho prežívania (Chien, Harbin, 2012; Delate-O'Connor, Farley, 2012; Guzman, Caal, 2014). Školy a rôzne organizácie hl'adajú cesty ako efektívne integrovat' sociálne učenie do školských tried a ich učebných plánov. Napríklad Nadácia Child Trends sa zameriava na sociálne zručnosti, ktoré pomáhajú žiakom zvládat' svoje emócie, správanie, vytrvat' k svojim ciel'om, zmenit' hodnotu učenia, vediet' kooperovat' s ostatnými a verit' vo svoje vlastné akademické úspechy.

\section{Sociálne zručnosti ako prediktor úspešnej socializácie}

Sociálne zručnosti definuje Elkins (In Hajkova, Strnadova, 2010) v oblasti medzil'udských vzt’ahov (angl. interpersonal behaviours) pomáhajúce nám vytvárat' priatel'ské vzt'ahy, zručnost' predstavit' sa, vediet' sa zapojit', požiadat' o láskavost', ponúknut' pomoc, dávat' a prijímat' komplimenty, ospravedlnit' sa; spojené s vrstovníkmi (angl. peer-related social skills), ktoré sú hodnotené vrstovníkmi a úzko súvisia is prijatím zo strany vrstovníkov, napríklad zručnost' kooperácie alebo požiadania o informáciu a jej prijatie; zamerané na potešenie učitel'a (angl. teacherpleasing social skills), ktoré sú spojené $\mathrm{s}$ úspechom v škole a zahíňajú počúvanie inštrukcií a počúvanie učitel’a; správanie zamerané na vlastnú osobu (angl. self-related behaviours), ktoré umožňujú žiakovi ohodnotit' sociálnu situáciu, zvolit' vhodnú zručnost' a určit' jej efektivitu, d'alej zvládat' stres, porozumenie pocitov a schopnost' kontrolovat' hnev; asertívne zručnosti (angl. assetiveness skills), ktoré pomáhajú žiakovi vyjadrit' svoje potreby, bez toho, aby musel použit' agresiu; a v neposlednom rade komunikačné zručnosti (angl. communication skills), ktoré zahŕňajú vnímavost' poslucháča, striedanie sa a poskytovanie vzájomnej spätnej väzby.

Sociálne zručnosti v kontexte školského prostredia predstavujú súbor kompetencií, ktoré ul'ahčujú začatie a udržiavanie pozitívnych sociálnych vzt'ahov (aj s opačným pohlavím), prispievajú $\mathrm{k}$ rovesníckemu prijatiu a rozvoju priatel'stva, vedú k uspokojivej úprave v škole, umožňujú jednotlivcom vyrovnat' sa a prispôsobit' sa požiadavkám sociálneho prostredia (Gresham, Van, Cook, 2006). V tomto kontexte svoju pozornost' upriamujú Gresham, Elliott (1990) na zručnost' spolupráce, ktorá predstavuje správanie prejavujúce pomoc spolužiakom, dodržiavanie pravidiel a rešpektovanie iných. Dalej na zručnost' asertivitu, ktorú považujú za iniciatívne správanie, schopnost' vediet' žiadat' iných o informácie, presadzovanie vlastnej osoby bez konfliktov a primerané reagovanie na iné osoby. A v neposlednom rade, na zručnost' empatia, ktorá vedie k záujmu a úcte k pocitom a názorom iných, schopnost' vediet' aktívne počúvat' a vcítit' sa do pocitov svojich spolužiakov, vrstovníkov. Goleman (1995) uvádza, že empatia je porozumenie záujmom a emóciám druhých l'udí, čiže schopnost' vidiet' situáciu z ich hl'adiska. Elliott et al. (2001) považujú tieto sociálne zručnosti za dôležité $\mathrm{v}$ úspešnej socializácii i vakademickom úspechu u všetkých žiakov. Významné sú aj v prevencii negatívneho hodnotenia zo strany iných, a preto sa považujú za dôležité aspekty inkluzívnej školy. Jednotliví žiaci môžu mat' sociálne zručnosti rozvinuté na odlišnej úrovni. Kým jeden žiak toleruje ostatných v triede, vie sa skamarátit', vie počúvat' druhých, tak iný žiak sa môže prejavovat' ako samotár, prípadne nevie akým spôsobom nadviazat' bežnú komunikáciu. Takéto rozdiely $\mathrm{v}$ školskom prostredí je nutné eliminovat', aby sme predišli konfliktom $\mathrm{v}$ triede, agresívnemu správaniu, prípadne až sociálnemu vylúčeniu. Sociálnym zručnostiam môžeme rozumiet' cez schopnosti, ktoré využívame pri styku s inými l’ud'mi v spoločnosti (Patrick, 2011). Sú založené na sociálnych normách našej spoločnosti a hovoria nám, aké správanie a postoje sa považujú za normálne a prijatel'né v určitých spoločenských situáciách. Dovol'ujú nám komunikovat' medzi sebou s určitou predvídatel'nost'ou, t.j. môžeme lepšie rozumiet' jeden druhému a vzájomne si rozumiet'. Žiaci s rozvinutými sociálnymi 
zručnost'ami sú v spoločnosti považovaní za schopných a úspešných. Ostatní ich majú väčšinou radi, zatial' čo žiaci, ktorí sociálne zručnosti neovládajú, sú považovaní sa neschopných. Potom následné zlyhanie $\mathrm{v}$ učení sociálnych zručností môže viest' $\mathrm{k}$ izolácii, $\mathrm{k}$ pocitu samoty, $\mathrm{k}$ frustrácii, pocitu odmietnutia a $\mathrm{k}$ malému sebavedomiu. Preto ich Kročanova $(2003,2012)$ považuje za kl’účový faktor determinujúci úspešnost' sociálnej integrácie. Prítomné sociálne zručnosti ovplyvňujú, ako je žiak prijímaný vrstovníkmi, ako sa k nemu správajú a ako ho rešpektujú. Štúdie má autorka zamerané hlavne na žiakov so sluchovým postihnutím, ale aj u iných druhoch znevýhodnenia hrajú sociálne zručnosti ústrednú úlohu v participácii žiakov v sociálnej skupine. Aj výsledky výskumov Zbortekovej (2012) naznačujú, že žiaci so zdravotným postihnutím sú v dennom kontakte so svojimi intaktnými spolužiakmi opakovane konfrontovaní s pocitom osamelosti, prejavov l'ahostajnosti, či dokonca odmietania. Nedostatočné sociálne začlenenie vnímame ako závažný problém, ktorý môže komplikovat' formovanie identity jedinca. $\mathrm{Z}$ toho dôvodu by sme sa mali, v prvom rade, zamerat' na rozvíjanie sociálnych zručností tak ako u žiakov so ŠVVP, aj u žiakov intaktných. Eliminácia rozdielov sociálnych zručností u týchto žiakov by mohla mat' za následok aktívne sociálne začleňovanie, dobrú spoluprácu a porozumenie medzi žiakmi navzájom.

Zahraniční autori Acker, Bost, Coe, Farmer, Henley Pearl, Rodkin (1998) sa zaoberajú sociálnou interakciou žiakov s postihnutím na bežných školách. Elliott, Demarey, Maleckie (2001) zastávajú názor, že práve sociálne zručnosti sú dôležité v úspešnej socializácii i v akademickom úspechu u všetkých žiakov a považujú ich za významné aj v prevencii negatívneho hodnotenia zo strany iných. Uvádzajú, že sociálne zručnosti sú dôležité aspekty inkluzívnej školy a vidia súvislost' medzi akademickými kompetenciami a sociálnymi zručnost’ami, ktorým je potrebné venovat' pozornost' tak ako na základnej, aj na strednej škole. Priamy vzt’ah medzi sociálnymi zručnost'ami a akademickými kompetenciami potvrdili viaceré výskumy (Asher, Bursuch, 1986; Coie, Krehbiel 1984; Maleckie, Elliott, 1999), ktoré zdôrazňujú aj relevantnost' medzi sociálnymi zručnost’ami a druhom znevýhodnenia, resp. stupňom postihnutia žiaka. Guralnick, Neville, Hammond, Connor (2006) popisujú ako sú priatel'stvá podstatné vo vzt'ahoch medzi žiakmi a poskytujú komplex rozvoja osobnosti žiaka. Z toho dôvodu je problematika sociálnych zručností v školskom prostredí značná. Preto chceme zistit' do akej miery ovládajú sociálne zručnosti intaktní žiaci a žiaci so ŠVVP v podmienkach bežnej základnej školy.

\section{Výskumná vzorka}

Výskumná vzorka je tvorená 105 respondentmi nižšieho sekundárneho stupňa vzdelávania, resp. žiakmi 9. ročníka vo veku od 14 do 15 rokov. Dôvod výberu žiakov 9. ročníka považujeme za najefektívnejší, pretože žiaci sa nachádzajú v tranzitnom období škol'ovania, kde možno záverom konštatovat' ich pripravenost' adaptácie na nové pokračujúce školské prostredie. $Z$ celkového počtu respondentov je 44 (42\%) chlapcov a $61(58 \%)$ dievčat. Výskumná vzorka je tvorená žiakmi zo slovenských bežných základných škôl v Nitre a v Košiciach. Výskum sa realizoval v rozmedzí október 2015 - november 2015.

\section{Metódy}

Škála sociálnych zručností (SSR) je výskumný nástroj zameraný na detekciu miery sociálnych zručností u žiakov na druhom stupni základných škôl. Výskumný nástroj vznikol ako inšpirácia na základe v zahraničí často používaného dotazníka Social Skills Rating System - Student Forms (SSRS) od Greshama a Elliotta z roku 1990, ktorý je pôvodne zameraný na meranie miery niekol'kých osobných vlastností prejavujúcich sa u žiakov v školskom prostredí. Identifikuje nevhodné/problémové správanie žiakov, sociálne zručnosti žiakov a schopnost' učit' sa. Pôvodná škála je 
zameraná na sociálne zručnosti, problémové správanie a akademické kompetencie detí a dospievajúcich od 5 až 18 rokov. Pôvodnú škálu vypĺñajú žiaci (sociálne zručnosti), učitelia (sociálne zručnosti, problémové správanie, akademické kompetencie) a rodičia (sociálne zručnosti, problémové správanie). Nástroj je určený pre deti a dospievajúcich, ktorí sa prejavujú v problémovom správaní.

Pre potreby nášho výskumu bola preložená subškála Sociálne zručnosti, ktorá je zameraná na detekciu miery sociálnych zručností žiakov. Preklad škály do slovenčiny bol uskutočnený obvyklým spôsobom s následným spätným prekladom (preklad prebiehal v časovom rozpätí od júna do septembra 2015). Jednotlivé položky v pôvodnej škále sú formulované na porozumenie textu det’om a dospievajúcim od 5 až 18 rokov. $Z$ toho dôvodu boli položky prispôsobené ciel'ovej výskumnej skupine (14a 15-roční žiaci). Prispôsobenie spočívalo $\mathrm{v}$ zameraní položiek konkrétne na spolužiakov, ale pritom bola zachovaná obsahová štruktúra jednotlivých položiek.

Vnútorná homogenita výskumného nástroja bola overená pomocou faktorovej analýzy (Principal Axis Factoring; rotácia Varimax; obmedzenie faktorov na 3 pomocou Eigenvalues), na základe, ktorej boli identifikované tri subškály. Jednotlivé subškály sú sýtené faktormi od 0.32 až 0.70 (Spolupráca: 0.39-0.56; Asertivita: 0.49-0.70; Empatia: 0.32-0.41. V jednotlivých subškálach sme nebrali do úvahy položky, ktoré nesýtia faktor na minimálnej hladine 0.30 . Ako problematický faktor sa javí subškála Sebakontrola, kde položky tejto subškály nedosahovali minimálne stanovené sýtenie faktoru (0.30). Z toho dôvodu subškála bola odstránená, čo si vyžaduje d’alšiu konštrukciu, či rekonštrukciu položiek.

Následne upravená subškála Sociálne zručnosti pozostáva z 3 premenných/subškál: Spolupráca, Asertivita a Empatia. Jednotlivé subškály sú tvorené 4 položkami pre Spoluprácu, Asertivitu a 5 položkami pre premennú Empatiu. Pri administrácii žiaci odpovedajú na otázky pomocou miery súhlasu na škále Likertovského typu pozostávajúcej z 5 stupňov. Reliabilita nástroja meraná Cronbachovým Alfa koeficentom celého nástroja bola uspokojivá $(\alpha=0.740)$. Pre jednotlivé subškály koeficient reliability nadobúda: Spolupráca $\alpha=0.53$; Asertivita: $\alpha=0.59$; Empatia: $\alpha$ $=0.75$.

\section{Výsledky}

Výsledky štatistických analýz sú prezentované v Tabul'kách 1 a 2, a v Grafoch 1 a 2. Štatistické analýzy boli realizované v štatistickom programe IBM SPSS 20. Na popis a komparáciu výskumných skupín v jednotlivých premenných dotazníka SSRS boli použité metódy deskriptívnej štatistiky (M, SD, SEM, Min, Max, šikmost', špicatost') a metódy inferenčnej štatistiky (Kolmogorov-Smirnov R test; Studentov t- test). Grafy boli spracované v programe MS Excel.

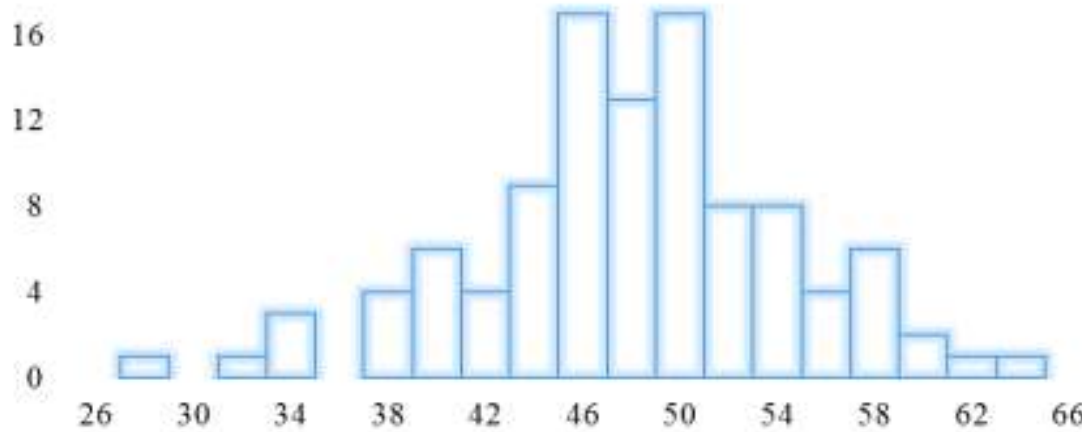


Graf 1: Rozloženie ziskaných dát

Pri zist'ovaní normality výskumných dát boli použité metódy: šikmost' rozdelenia (Skewness), špicatost' údajov (Kurtosis) a Kolmogorov-Smirnov $\mathrm{R}$ koeficient. Šikmost' rozdelenia pre celú množinu údajov je $\mathrm{SK}=-0.34$, kým na úrovni jednotlivých škál sa pohybuje od $\mathrm{SK}=-0.64$ až $\mathrm{SK}=-0.43$. Špicatost' pre celú množinu údajov je $\mathrm{KU}=0.16$, kým na úrovni jednotlivých škál sa pohybuje od $\mathrm{KU}=$ 0.08 až KU $=1.51$ (Tabul'ka 1). Vzhl'adom na to, že sa špicatost' množiny údajov v premennej Spolupráca pohybuje mimo stanoveného intervalu ( -1 až 1), bola aplikovaná metóda Kolmogorov-Smirnov R test, na základe ktorej sme potvrdili normalitu množiny údajov $(\mathrm{R}=1.193 ; \mathrm{p}=0.116)$ a na d'alšie analýzy sme volili parametrické testy. Kolmogorov-Smirnov R koeficient nebol štatisticky významný ani na úrovni jednotlivých výskumných skupín (Intaktní žiaci: $\mathrm{R}=1.197 ; \mathrm{p}=0.114 ;$ Žiaci so $\check{S} V V P: \mathrm{R}=0.696 ; \mathrm{p}=0.719)$.

\begin{tabular}{l|cccccccc} 
Faktor & $N$ & $M$ & $S D$ & SEM & Min & Max & SK & $K U$ \\
\hline Spolupráca & 105 & 15.10 & 2.51 & 0.25 & 5 & 20 & -0.64 & 1.51 \\
Asertivita & 105 & 14.14 & 3.29 & 0.32 & 4 & 20 & -0.55 & 0.40 \\
& 105 & 17.95 & 3.61 & 0.35 & 7 & 25 & -0.43 & 0.08
\end{tabular}

Tabul'ka 2 Deskriptívna štatistika výskumných dát

*Pozn.: N-počet; $M$ - priemer; SD- štandardná odchýlka; SEM- štandardná chyba priemeru; Min- minimálne získané skóre v príslušnej skupine; Max-minimálne ziskané skóre v príslušnej skupine; $S K$ - šikmost' rozdelenia; $K U$ - špicatost' množiny údajov

V Tabul'ke 1 sú prezentované popisné údaje o intenzite jednotlivých premenných v celom výskumnom súbore. Skóre všetkých premenných sa pohybuje nad aritmetickým priemerom (pre premenné Kooperácia a Asertivita $\mathrm{M}=12.00$; pre premennú Empatia $\mathrm{M}=15$ ).

\begin{tabular}{l|l|lcc|lcc} 
Premenná & Skupina & $n$ & $M$ & $S D$ & $d f$ & $t$ & $P$ \\
\hline \multirow{2}{*}{ Spolupráca } & INT & 83 & 15.12 & 2.510 & & & \\
& ŠVVP & 22 & 15.05 & 2.572 & & & \\
Asertivita & INT & 83 & 14.42 & 3.254 & 103 & 1.643 & 0.103
\end{tabular}




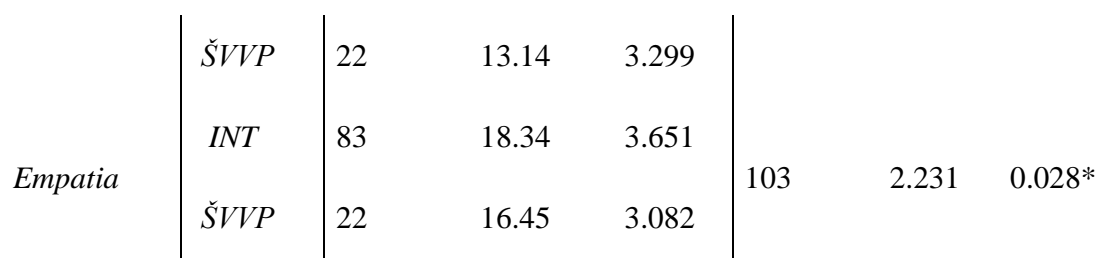

Tabul'ka 3: Rozdiely v premenných dotazníka SRSS u intaktných žiakov a žiakov so špeciálnymi výchovno-vzdelávacími potrebami

*Pozn.: INT- intaktni žiaci; ŠVVP- žiaci so špeciálnymi výchovno-vzdelávacími potrebami; $n$ - počet; $M$ - priemer; $S D$ - štandardná odchýlka; $d f$-stupne vol'nosti; $t$ Studentov t- test; p- hladina štatistickej významnosti; *- signifikantný rozdiel na hladine štatistickej významnosti 0.05 .

Pri hodnotení sociálnych zručností na úrovni jednotlivých subškál dotazníka SSRS u intaktných žiakov a žiakov so ŠVVP sme zistili štatisticky významný rozdiel v premennej Empatia $(\mathrm{t}=2.231 ; \mathrm{p}=0.028)$ na hladine 0.05 (Tabul'ka 2). Intaktní žiaci vykázali signifikantne vyššie priemerné skóre o 1.89 bodu, v porovnaní so žiakmi so špeciálnymi výchovno-vzdelávacími potrebami. Intaktní žiaci prejavili vyššie priemerné skóre aj na úrovni ostatných premenných dotazníka SSRS (v premennej Spolupráca o 0.07 bodu a v premennej Asertivita o 1.28 bodu). Avšak, tieto rozdiely neboli štatisticky významné.

\title{
$\square$ Intaktní žiaci $\quad \square$ Žiaci so ŠVVP
}

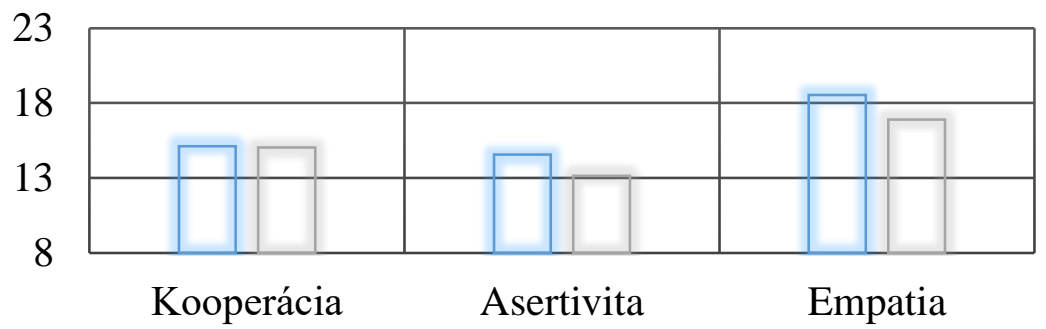

Graf 1: Rozdiely v premenných dotazníka SRSS u intaktných žiakov a žiakov so špeciálnymi výchovno-vzdelávacími potrebami

\begin{abstract}
Diskusia a záver
Štúdia je adresovaná na sociálne zručnosti dvoch typov žiakov (intakní a žiaci so ŠVVP) bežnej základnej školy. Rozdiely v priemeroch sme pozorovali v premennej Kooperácia o 0.07 bodu a vremennej Asertivita o 1.28 bodu, ale štatisticky významný rozdiel bol zistený v premennej Empatia $(\mathrm{F}=2.231 ; \mathrm{p}=0.028)$ na hladine 0.05 (Tabul'ka 2). Výsledky štúdie (Frostad, Pijl, 2007) tiež poukazujú na fakt, že intaktní žiaci dosahovali v priemere lepšie hodnoty sociálnych zručností ako ich spolužiaci so ŠVVP. Sme toho názoru, že premenná Empatia poukazuje na dôležitý problém v školskom prostredí, ktorý je potrebný riešit. Za hlavný dôvod, že žiaci so ŠVVP mali signifikantne nižšie skóre považujeme fakt, že títo žiaci často vzbudzujú
\end{abstract}


u druhých l'útost' (Vagnerova, 2008). V triede sa to môže prejavit' slabou komunikáciou alebo asertivitou zo strany žiakov so ŠVVP. Ďalej sa domnievame, že títo žiaci nechcú byt' v centre pozornosti a aj z toho dôvodu sa radšej stiahnu a svoje názory, postoje v triede neprejavia. Viaceré výskumy (Greenspan, Granfield, 1992; Garrison-Harrell, Kamps, 1997; Pfiffner, McBurnett; 1997; Scheepstra et al., 1999; Soresi, Nota, 2000; Monchy et al., 2004) upriamujú pozornost' na žiakov so ŠVVP dosahujúc nižšiu mieru sociálnych zručností, čo spájajú s nedostatočným nadväzovaním vzt’ahov medzi členmi skupiny. S tým úzko súvisia výskumy Matejceka, Vagnerovej (2006), Trlicovej (1995), Ucna (2001, 2002), ktorí poukazujú zase na nízke sociálne postavenie žiakov so ŠVVP v bežnom školskom prostredí. Seidler, Belikova, Dufekova (2013) uvádzajú, že práve jednou z dôležitých podmienok inkluzívneho procesu je vybudovanie takého sociálneho priestoru, ktorý umožní žiakovi zvládnut' úlohy, ktoré škola prináša. Žiaci sa stretávajú s novou situáciou, s ktorou nemajú skúsenost' z bežného života, čo na druhej strane nemusí platit' vždy. V takejto triede na základnej škole sa špecifikuje sociálna interakcia, sociálna komunikácia, vytvárajú sa nové sociálne vzt’ahy na škále akceptácie, solidárnosti, pomoci alebo aj naopak nevraživosti, odporu či odmietania, čo ma súvis aj s empatickým prejavom. Z toho by nám mala vyplynút' aj zmena našich názorov, postojov a vnútornej motivácie, pretože len zmenou našej filozofie (samotného jedinca) môžeme zmenit' aj celú spoločnost'. Vagnerova (2008) uvádza, že postoje spoločnosti môžu byt' natol'ko silné, že dokážu ovplyvňovat' aj subjektívne hodnotenie žiaka s postihnutím. Nízka miera empatie môže viest' k odmietaniu kontaktov a priatel'stiev, čo sa môže diat' práve v školskom prostredí.

Záverom konštatujeme, že by sme sa mali zamerat' na zvyšovanie sociálnych zručností u žiakov so ŠVVP, napríklad tréningom sociálnych zručností. Zámerom by malo byt' rozvíjanie a udržiavanie kontaktov, vzt'ahov a priatel'stiev medzi rovesníkmi, eliminácia sociálneho vylúčenia, agresívnych prejavov alebo nízkeho sebapoňatia. Sociálne zručnosti teda považujeme za prediktor úspešnosti v živote žiakov, nielen $\mathrm{v}$ ich d'alšom pokračujúcom štúdiu, ale v ich živote ako takom, kde sa budú neustále stretávat's intaktnou populáciou. Jordán et al. (1991) interpretuje, že takéto programy vzájomne podporujú zdravý duševný a sociálny vývoj. Sú založené na sociálnych a emocionálnych aspektoch poukazujúcich na pevný základ sociálnych zručností zameraných na pomoc žiakom vyrovnat' sa s viacerými výzvami vo svojom živote (Elias, 1995; Elias et al., 1997). Sú navrhnuté tak, aby vytvorili bezpečné a kooperatívne prostredie $\mathrm{v}$ triede orientované na intelektuálny, sociálny a emocionálny vývoj žiakov. Programy na rozvoj sociálnych zručností zdôrazňujú aj elimináciu nevhodného až agresívneho správania (Grossman et al., 1997), zlepšenie sociálneho prispôsobenia, vrstovníckych vzt’ahov (Battistich, 2003) a prejavov vlastných pocitov (Greenberg et al., 1995).

\section{Bibliographic references}

BENDER, W. N. - WALL, M. E. 1994. Social-emotional development of students with learning disabilities. Learning Disability Quarterly, 17, pp. 323-341.

BURSUCH, W. W. - ASHER, S. R. 1986. The relationship between social competence and achievement in elementary school children. Journal of Clinical Child Psychology, 15, pp. 41-49.

BUYSSE, V. - DAVIS GOLDMAN, B. - SKINNER, M. L. 2002. Setting effects on friendship formation among young children with and without disabilities. Exceptional Children, 68, pp. 503-517.

CAMBRA, C. - SILVESTRE, N. 2003. Students with special educational needs in the inclusive classroom: Social integration and self-concept. European Journal of Special Needs Education, 18, pp. 197-208. 
CHIEN, N. - HARBIN, V. 2012. Encouraging the development of key life skills in elementary school-age children: A literature review and recoomendations to the Tauck Family Foundation Washington. Child Trends

COIE, J. D. - KREHBIEL, G. 1984. Effects of academic tutoring on the social status of low-achieving, socially-rejected children. Child Development.55 (4), pp. 14651478 .

DELATE-O CONNOR, B. L. - FARLEY, CH., ET AL. 2012. Essential Self Management Skills: Summary of Research. Child Trends. .

ELLIOTT, S. N. - MALECKI, CH. K. - DEMARAY, M. K. 2001. New Direcions in Social Skills Assessment and Intervention for Elementary and Middle School Students. FERGUSON, D. L. 2008. International trends in inclusive education: The continuing challenge to teach each one and everyone. European Journal of Special Needs Education, 23, pp. 109-120.

FREDERICKSON, N. - DUNSMUIR, S. - LANG, J. - MONSEN, J. J. 2004. Mainstream special school inclusion partnerships: Pupil, parent and teacher perspectives. International Journal of Inclusive Education, 8, pp. 37-57.

FROSTAD, P. - PIJL, S. J. 2007. Does being friendly help in making friends? The relation between the social position and social skills of pupils with special needs in mainstream education. European Journal of Special Needs Education.

HAJKOVA, V. - STRNADOVA, I. 2010. Inkluzivni vzdelavani. Teorie a praxe. Praha : Grada Publishing, a.s.

GARRISON-HARRELL, L. - KAMPS, D. 1997 The effects of peer networks on social-communicative behaviors for students with autism, Focus on Autism and Other Developmental Disabilities, 12(4), pp. 241-254.

GOLEMAN, D. 1995. Emocni inteligence. 2. vyd. Praha : Metafora.

GREENSPAN, S. - GRANFIELD, J. R. 1992. Reconsidering the construct of mental retardation: implication of a model of social competence, American Journal of Mental Retardation, 96, pp. 442-453.

GRESHAM, F. M. - ELLIOTT, S. N. 1990. Social skills rating systems.

GRESHAM, F. M. - VAN, M. B. - COOK, C. R. 2006. Social skills training for teaching replacement behaviors: Remediating acquisition deficits in at-risk students. Behavioral Disorders. 2006, 31(4), pp 363-377.

GURALNICK, M. J. - NEVILLE, B. - HAMMOND, M. A. - CONNOR, R. T. 2007. The friendships of young children with developmental delays. A longitudinal analysis. Journal of Applied Developmental Psychology, 28, pp. 64-79.

GURALNICK, M. J. - NEVILLE, B. - HAMMOND, M. - CONNOR, R. T. 2006. The Friendships of Young Children with Developmental Delays: A Longitudinual Analysis. J Appl Dev Psychol, 28(1), pp. 64-79.

GUZMAN, L. S. - CALL, ET AL. 2014. Memo: Tauck Family Foundation-Social Competence Item Development and Pilot Project. Child Trends.

KOSTER, M. - NAKKEN, H. - PIJL, S. J. - VAN HOUTEN, E. J. 2009. Being part of the peer group: A literature study focussing on the social dimension of inclusion in education. International Journal of Inclusive Education, 13, pp. 117-140.

KROCANOVA, L. 2003. Osobnostne a socialne determinanty dietata s postihnutim v integrovanom prostredi. Socialni procesy a osobnost, pp. 181-183.

KROCANOVA, L. 2012. Socialne zrucnosti deti so sluchovym postihnutim v beznej materskej skole. Efeta, 2(XXII), pp. 16-20.

LEE, S. H. - YOO, S. Y. - BAK, S. H. 2003. Characteristics of friendships between children with and without disabilities. Education and Training in Developmental Disabilities, 38, pp. 157-166.

MALECKI, CH. K. - ELLIOTT, S. N. 2002. Children's Social Behaviors as Predictors of Academic Achievement: A longitudinal Analysis. School Psychology Quarterly. 17 (1), pp. 1-23. 
MATEJCEK, Z. - VAGNEROVA, M. 2006. Socialni aspekt dyslexie. Praha: Nakladatelství Karolinum.

MONCHY, M. - PIJL, S. J. - ZANDBERG, T. 2004. Discrepancies in judging social inclusion and bullying of pupils with behaviour problems, European Journal of Special Needs Education, 19(3), pp. 317-330.

PATRICK, N. J., 2011. Rozvijeni socialnich dovednosti lidi s poruchami autistickeho spektra : tipy a strategie pro kazdodenni zivot. Praha : Portál, s.r.o.

PEARL, R. - FARMER, T. W. - ACKER, R. W. - RODKIN, P. C. - BOST, K. K. COE, M. - HENLEY, W. 1998. The Social Integration of Students with Mild Disabilities in General Education Classrooms: Peer Group Membership and PeerAssessed Social Behavior. The Elementary School Journal. 99(2), pp. 167-185.

PFIFFNER, L. J. - McBUMETTM, K. 1997. Social skills training with parent generalization: treatment effects for children with attention deficit disorder, Journal of Consulting and Clinical Psychology, 65(5), pp. 749-757.

SEIDLER, P. - BELIKOVA, V. - DUFEKOVA, A. 2013. [In] Akosti v terciarnom vzdelavani. Nitra : PF UKF $\mathrm{v}$ Nitre.

SCHEEPSTRA, A. J. M. - NAKKEN, H. - PIJL, S. J. 1999. Contacts with classmates: The social position of pupils with Down's syndrome in Dutch mainstream education. European Journal of Special Needs Education, 14, pp. 212-220.

SLOPER, T. - TYLER, S. 1992. Integration of children with severe learning difficulties in mainstream schools: Evaluation of a pilot study. Educational and Child Psychology, 9, pp. 35-45.

SOLLAROVA, E. 2008. Socializacia. Socialna psychologia. Bratislava : Polygrafické stredisko UK, pp. 168-180.

SORESI, S. - NOTA, L. 2000. A social skill training for persons with Down's syndrome, European Psychologist, 5(1), pp. 34-43.

TRLICOVA, K. 1995. Socialny status postihnuteho ziaka medzi zdravymi. Psychologia a patopsychologia dietata, 30(3), pp. 302-307.

UCEN, I. 2001. Socialny status ziakov v integrovanych triedach zakladnych skol. Psychologia a patopsychologia dietata. 36(4), pp. 329-337.

UCEN, I. 2002. Individualny socialny status ziakov zakladnych integrovanych skol verzus postoje k integracii. Psychologia a patopsychologia dietata. 37, 4, pp. 351356.

VAGNEROVA, M. 2008. Psychopatologie pro pomahajuce profese. Praha : Portál. ZBORTEKOVA, K. 2012. Socialna inkluzia ziakov so sluchovym postihnutim a moznosti jej podpory. Vychovny aspekt inkluzivnej edukacie a jeho dimenzie. Bratislava : IRIS, s.r.o., pp. 260-272.

Mgr. Eva Lörinczová

Mgr. Robert Tomšik

Department of Education

Faculty of Education

Constantine the Philosopher University

Drážovská cesta 4, 94974 Nitra

Slovakia

eva.lorinczova@ukf.sk

robert.tomsik@ukf.sk 